\title{
Runoff Estimation for Suggested Water Harvesting Sites in the Northern Jordanian Badia
}

\author{
Saad AlAyyash ${ }^{1}$, Rida Al-Adamat ${ }^{{ }^{*}}$, Hani Al-Amoush ${ }^{1}$, Odeh Al-Meshan ${ }^{2}$, Zahir Rawjefih ${ }^{3}$, \\ Akram Shdeifat ${ }^{1}$, Adnan Al-Harahsheh ${ }^{4}$, Mohammed Al-Farajat ${ }^{1}$ \\ ${ }^{1} \mathrm{Al}$ al-Bayt University, Mafraq, Jordan \\ ${ }^{2}$ Jordan Badia Research Programme, Amman, Jordan \\ ${ }^{3}$ Jordan University for Science and Technology, Irbid, Jordan \\ ${ }^{4}$ Mutah University, Karak, Jordan \\ Email: *ridaali@aabu.edu.jo
}

Received December 5, 2011; revised January 12, 2012; accepted February 17, 2012

\begin{abstract}
Jordan is characterized by severe weather conditions, therefore great temporal and spatial variations in rainfall; runoff and evaporation amounts are expected. Water harvesting has been practiced in Jordan throughout history for both irrigation and household purposes. A major research project was carried out in the Jordanian Badia on site selection criteria for rain water harvesting systems based on the integration between indigenous knowledge and the use of Geo-informatics. This work was followed by conducting a geophysical and soil investigation for five potential sites. In this study, GIS was used to investigate the potential of having enough runoff in the five selected sites to establish water harvesting dams based on rainfall, evaporation data and catchments' areas for the selected sites. It was found that the estimated runoff that could be harvested on annual basis at these sites varies between 0.2 Million Cubic Meters (MCM) in Alaasra site to $0.82 \mathrm{MCM}$ in Al-Manareh (Al-Ghuliasi) site. This indicates that these sites have the potential for small scale water harvesting that could be utilized by local livestock owners in the area to water their livestock.
\end{abstract}

Keywords: Water Harvesting; Rainfall; Runoff; Badia; Jordan

\section{Introduction}

Historically, arid lands have not invested in hydrological data acquisition such as flood volumes and rates, rainfall intensities and volumes, etc. Hydrological data collection such as rainfall intensities and flood volumes started in Jordan not long ago and it is concentrated in the humid parts of the country. In the last few years, the Badia started to receive more attention in documenting natural resources. This was as a result of the high population pressure in the limited urbanized areas of the country and the need to utilize the Badia for future development. Daily and annual rainfall recorders were installed on a very limited scale over the Badia. Flood volumes were not recorded in the Badia areas except in very few cases where limited time records were taken in small areas for specific projects [1].

Jordan is a developing country situated off the southeastern shores of the Mediterranean Sea between longitudes $35^{\circ}$ and $39^{\circ}$ East and latitudes $29^{\circ}$ and $33^{\circ}$ North (Figure 1). It is bounded in the North by Syria, in the East by Iraq and Saudi Arabia, in the South by Saudi Arabia and in the West by the River Jordan and the Dead *Corresponding author.
Sea. Its area is about $90,000 \mathrm{~km}^{2}$ and consists of various distinctive topographic units trending in a north-south direction. These units are the rift valley, high lands and the arid lands-desert region.

Jordan is characterized by severe weather conditions, therefore great temporal and spatial variations in rainfall; runoff and evaporation amounts are expected [2]. Water harvesting has been practiced in Jordan throughout history for both irrigation and household purposes $[3,4]$.

Reference [5] conducted a research on site selection criteria for rain water harvesting systems in the Jordanian Badia based on the integration between indigenous knowledge and the use of Geo-informatics. This research was based on the fact that water resources in Jordan are very limited and the country needs an intensive work to come up with more water resources to cover the sharp increase in water consumption for all sectors. A total of 200 stakeholders were invited from within the local communities in the Badia to provide the research team with some constrains that from their point of views are vital in choosing the suitable sites for water harvesting in their region. Also, they pointed out to certain locations within the Badia that could be utilized as a water har- 


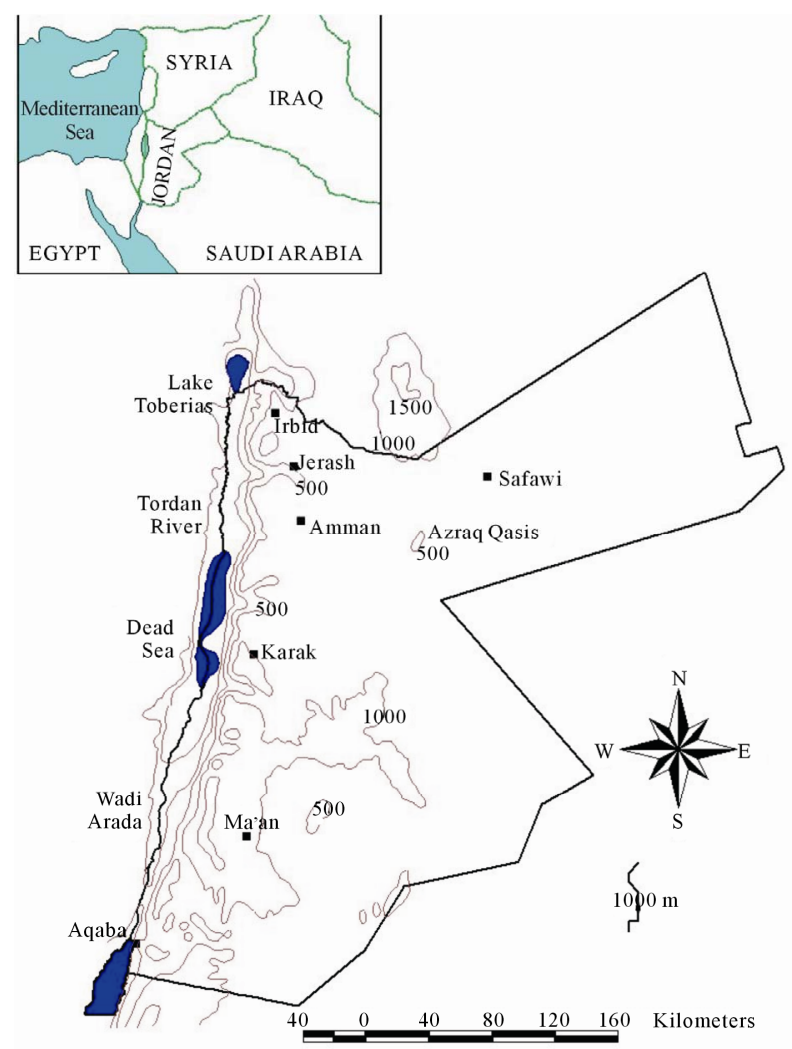

Figure 1. Location map of Jordan and general topography (in meters).

vesting sites based on their knowledge of the area as livestock owners. 30 sites in the Jordanian Badia were found to be suitable for water harvesting based on GIS analysis and local communities recommendations. Part of the project is conducting a geophysical and soil investigation for five potential sites selected by the project in order to determine their suitability for water harvesting.

This research aims to use GIS for investigating the potential of having enough runoff in the selected site to establish water harvesting dams based on the rainfall, evaporation data and catchments' areas for the selected sites. The application of GIS for catchemnt area analysis have been addressed in the literature in many researches (e.g. [6-10]).

\section{Methods}

\subsection{Investigated Area}

The study area is located in the northeastern Badia, which receives more rain on average than the other parts of the Badia. The annual rainfall varies from over 150 $\mathrm{mm}$ in the northwest to less than $50 \mathrm{~mm}$ in the southeast with an average of $70-80 \mathrm{~mm}$. Rainfall as thunderstorms, characterized by irregular intensity and duration, forms the greatest part of total precipitation in the area. Rainfall occurs mostly during winter months (October to April) with the highest intensities in the months December to February. The annual mean temperature is $15^{\circ} \mathrm{C}$ with a mean monthly range of $8^{\circ} \mathrm{C}-28^{\circ} \mathrm{C}$, January to July. Evaporation rates are in general very high, with an average daily potential evaporation range of $3-17 \mathrm{~mm} /$ day, January to July [11].

The basaltic rocks cover $11,000 \mathrm{~km}^{2}$ of the northeastern Badia. Gentle slopes and relatively flat topography characterize the surface. The surface elevation is mostly 600 $1100 \mathrm{~m}$ above sea level; highest in the northeast (Figure 2). Geological variation is reflected in the geomorphology; faults have developed into Wadis but the sub-surface rocks made the development of channel networks very limited except in some parts where the weathering rates are high. Large boulders are distributed in the north and east of the area where the younger basalt is found. On the other hand, smaller rocks are found in the western part of the Badia where older basalt and higher rainfall helps weathering. The poor channel network results in blockages across most of the water courses in the Badia. These blockages create natural pools in the depressions where most of the runoff ends and evaporates leaving salty fine soil. The depressions (qa'a) are widely distributed in the Badia and form a major part of the surface geomorphology. Another type of depression (marab) is formed in the course of major channels. The marabs are formed from blockages that are not substantial enough to create pools but which impeed runoff which has led to soil accumulation. Flood water that does not infiltrate into the soil finds its way out of the marab. This process results in renewing the marab soil; only the coarse soil

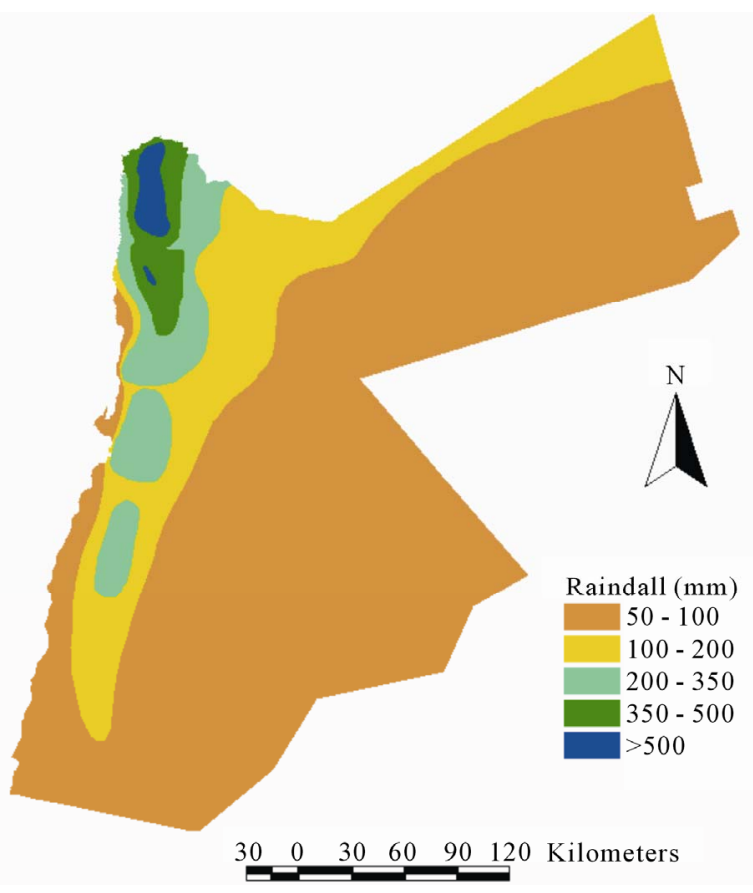

Figure 2. Jordan rainfall isohyets map [12]. 
particles have the chance to settle, resulting in good productive soil for range land vegetation and some seasonal crops such as barley and wheat. The parent soil material and the climatic parameters control the soil types and properties. In the northeast Badia, the soil is derived from basaltic lava and its development influenced by topography and weathering. Most of the soils are of depositional origin, which is dominant for arid lands. On steep slopes with high erosion residual soils occur on the rocks. Soils include well developed xerochrepts in the areas of older basalt flows and high weathering effect, and weakly developed xerothents on the more recent basalt flow [1].

\subsection{Data Collection}

Table 1 lists the secondary data sets that have been obtained from different government agencies in Jordan and from previous research in order to achieve the main objectives of this research. Also the average rainfall data for Jordan (Figure 2) is used to find the average rainfall for each catchment.

\section{Data Analysis and Results}

\subsection{Runoff Simulation}

The hydrological parameters which are required for rainfall-runoff simulation, can be defined in various ways depending on the simulation method. Understanding the approach used in calculating or estimating these parameters is necessary before using them in rainfall-runoff simulation. In areas where no or very limited records on rainfall-runoff, such as the case of this study, the best way is to use simulation method with as few estimated parameters as possible. A simple model is the Rational equation, which calculates the runoff volume using the catchment area, rainfall volume and runoff coefficient. The annual runoff volume for a catchment is estimated as follow:

\section{Runoff Volume $=$ Catchment Area $\times$ Annual Rainfall $\times$ Annual Runoff Coefficient}

The catchment areas can be identified using available maps whereas the average rainfall volumes are calculated using rainfall records of the study area. The runoff coefficient is the key parameter in this model.

Table 1. The secondary data sets used in this research and their sources.

\begin{tabular}{ccccc}
\hline $\begin{array}{c}\text { Map } \\
\text { type }\end{array}$ & Date & Format & Scale & Source \\
\hline $\begin{array}{c}\text { Contour } \\
(25 \mathrm{~m})\end{array}$ & 1995 & ArcGIS & $1: 250,000$ & $\begin{array}{c}\text { Goographic Centre } \\
\text { Goyal Jordanian }\end{array}$ \\
Wadis & & Al-Adamat et al., \\
Rainfall & 2007 & & & \begin{tabular}{c} 
[13] \\
\hline
\end{tabular} \\
\hline
\end{tabular}

\subsection{Runoff Volumes}

The annual rainfall for each catchment is estimated using the Jordan rainfall isohyets map (Figure 2). The first four catchments (\# 1, \# 2, \# 3 and \# 4) are within the rainfall range of $100-200 \mathrm{~mm}$ where the last catchment (\#5) is located within the rainfall range of $50-100 \mathrm{~mm}$ (Figure 3).

This coefficient depends on many factors, the main are the average slope of the catchment, the geomorphology and land cover of the catchment and the channel density within the catchment area.

Reference [14], found that the runoff coefficient for a single storm varies between $13 \%$ and $20 \%$ and also the rainfall data for Safawi Weather Station showed that only $4 \%$ of the storms exceeds $8 \mathrm{~mm}$ which is the threshold of a storm depth that could create runoff, sing these figures, the annual runoff coefficient for catchments in the Northern Jordan Badia can be estimated to vary between 5 and $8 \%$ [14].

Catchment \# 1 (Ghadeer Al-Naqa) (Figure 4): the catchment average slope is nearly flat and the area is heavily cultivated which suggests that most of the rainfall is retained within the loose soil, but with the good density of channel network and relatively high slope, the runoff could be estimated at $7 \%$.

Catchment \# 2 (Al-Manareh (Al-Ghuliasi)) (Figure 5): this catchment covers area mostly bare lands with areas cultivated with rain-fed crops. The bare lands have good cover of small rocks which helps in creating more runoff. All this combined with high slope leads to estimate the runoff coefficient of $8 \%$.

Catchment \# 3 (Alaasra) (Figure 6): this catchment covers area mostly bare lands with good cover of rocks. The area slope is relatively high and the estimated runoff coefficient can easily exceeds $8 \%$

Catchment \# 4 (Wadi Ali (Al-Abed)) (Figure 7): this

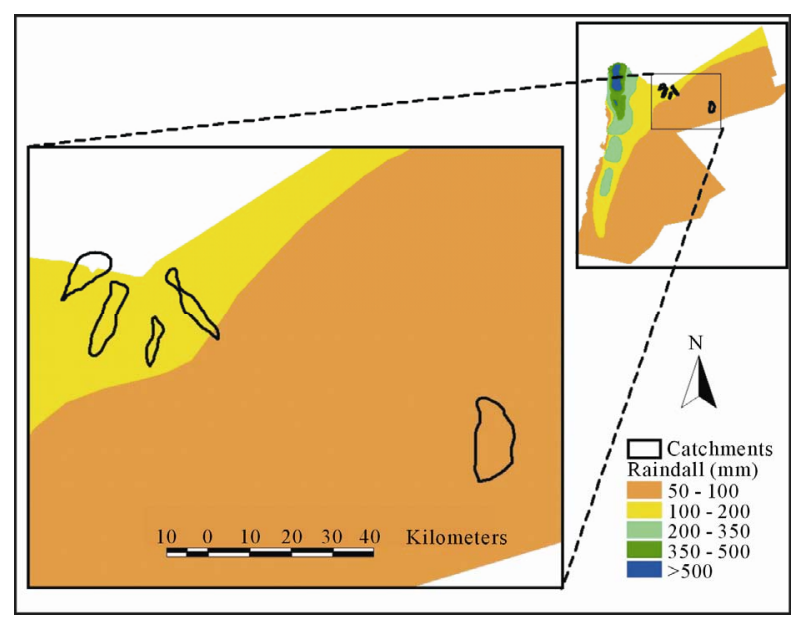

Figure 3. The location of catchment areas and rainfall isohyets. 


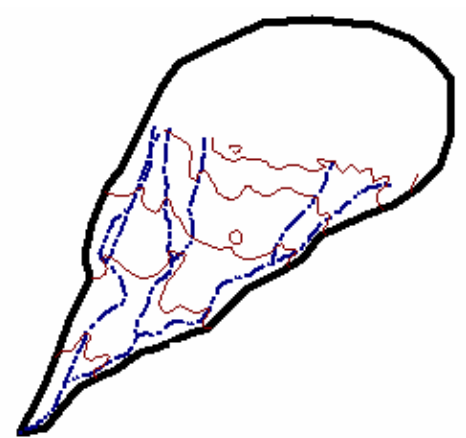

Figure 4. Catchment area \# 1 (Ghadeer Al-Naqa).

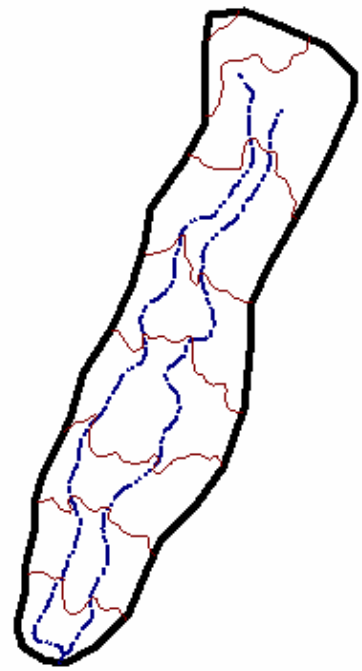

Figure 5. Catchment area \# 2 (Al-Manareh (Al-Ghuliasi)).

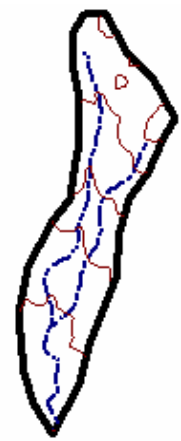

Figure 6. Catchment area \# 3 (Alaasra).

catchment covers area mostly bare lands with some rock gravel land cover. The good channel network density and medium catchment slope suggests that the runoff coefficient is estimated at $8 \%$.

Catchment \# 5 (Al-Subhi) (Figure 8): this catchment covers bare land. The catchment slope is nearly flat with many mudflats that retain most of the created runoff. All these factors suggest that the overall runoff coefficient is estimated at its lower limit of 5\%. Table 2 provides a summary for the hydrologic parameters in the targeted

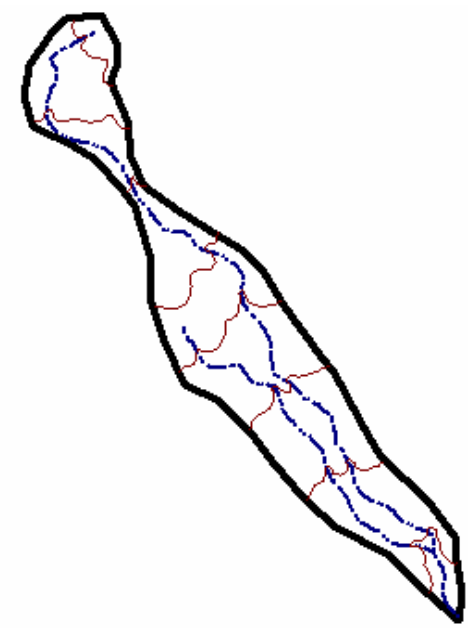

Figure 7. Catchment area \# 4 (Wadi Ali (Al-Abed)).

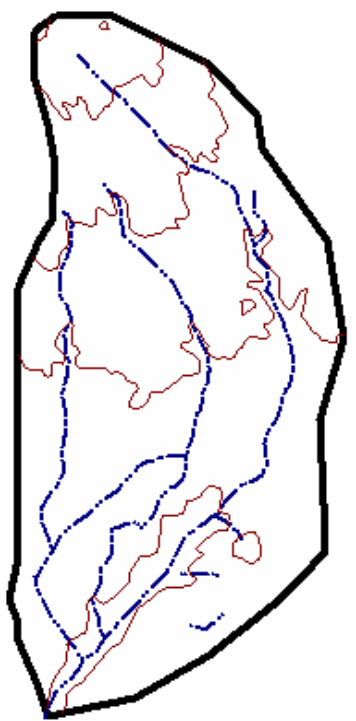

Figure 8. Catchment area \# 5 (Al-Subhi).

catchments and the estimated runoff volumes. This table shows that the estimated runoff that could be harvested on annual basis at these sites varies between 0.2 Million Cubic Meters (MCM) in Alaasra site to $0.82 \mathrm{MCM}$ in Al-Manareh (Al-Ghuliasi) site. This indicates that these sites have the potential for small scale water harvesting that could be utilized by local livestock owners in the area to water their livestock.

\section{Discussion and Conclusion}

Given the geomorphology of the area, which is defined by its bare land with some boulder cover and the distribution of small mud flats, the estimated values of the runoff coefficients are relatively low. With the lack of measured rainfall-runoff data, the estimated runoff using conservative runoff coefficient gives lower values than the actual ones. Other factor that affects the runoff is the 
Table 2. The hydrologic parameters for the targeted catchments and the estimated runoff volumes.

\begin{tabular}{|c|c|c|c|c|c|}
\hline ID & 1 & 2 & 3 & 4 & 5 \\
\hline Catchment Name & Ghadeer Al-Naqa & Al-Manareh (Al-Ghuliasi) & Alaasra & Wadi Ali (Al-Abed) & Al-Subhi \\
\hline Catchment Area $\left(\mathrm{km}^{2}\right)$ & 44.83 & 68.43 & 21.22 & 62.32 & 140.41 \\
\hline Main Channel Length (km) & 15.58 & 20.85 & 12.11 & 23.20 & 25.20 \\
\hline Highest Elevation (m) & 1200 & 1100 & 1000 & 1150 & 850 \\
\hline Lowest Elevation (m) & 850 & 750 & 750 & 750 & 700 \\
\hline Average Slope (\%) & 2.25 & 1.68 & 2.06 & 1.72 & 0.60 \\
\hline Annual Rainfall (mm) & 150 & 150 & 120 & 120 & 70 \\
\hline Annual Runoff Coefficient (\%) & 7 & 8 & 8 & 8 & 5 \\
\hline Runoff Volume (MCM) & 0.47 & 0.82 & 0.20 & 0.60 & 0.49 \\
\hline
\end{tabular}

poor infiltration of the study area soils where the infiltration rate drops very rapidly; once the initial abstraction is satisfied, most of the remaining rainfall is translated into runoff.

In this study, five catchment areas for suggested water harvesting sites in the Northern Jordanian Badia were investigated and characterized in order to determine whether these sites have the potential for establishing water harvesting schemes. The annual runoff volume for each catchment area was estimated based on the using a simple equation that take into consideration the catchment area, annual rainfall and annual runoff coefficient. GIS was used in determining the catchment area, annual rainfall and determining the potential runoff volume for each catchment. It was found that the estimated annual runoff that could be utilized for water harvesting is 0.47 MCM at Ghadeer Al-Naqa, 0.82 MCM at Al-Manareh (Al-Ghuliasi), 0.2 MCM at Alaasra, 0.6 MCM at Wadi Ali (Al-Abed) and $0.49 \mathrm{MCM}$ at Al-Subhi. Based on these results, it is recommended to establish a small size water harvesting sites at these sites. This will benefit the local community in the area in providing them with the needed water to water their livestock.

\section{Acknowledgements}

The authors of this research would like to acknowledge that this research was funded by The Scientific Research Fund/Jordan Ministry of Higher Education.

\section{REFERENCES}

[1] S. M. AlAyyash and F. N. Nnadi, "Surface Water Management in Arid Lands of Jordan with GIS Application," Proceedings of American Water Resources Association Summer Specialty Conference, Decision Support Systems for Water Resources Management, Snowbird, Utah, 2730 June 2001.

[2] Z. S. Tarawneh, N. A. Hadadin and A. N. Bdour, "Poli- cies to Enhance Water Sector in Jordan," American Journal of Applied Sciences, Vol. 5, No. 6, 2008, pp. 698704. doi:10.3844/ajassp.2008.698.704

[3] D. Prinz, "Water Harvesting: Past and Future,” In: L. S. Pereira, Ed., Proceedings of Sustainability of Irrigated Agriculture, NATO Advanced Research Workshop, Vimeiro, Balkema, Rotterdam, 21-26 March 1996, pp. 135-144.

[4] R. A. AbdelKhaleq and I. Ahmed Alhaj, "Rainwater Harvesting in Ancient Civilizations in Jordan," Water Science \& Technology: Water Supply, Vol. 7, No. 1, 2007, pp. 8593. doi:10.2166/ws.2007.010

[5] R. Al-Adamat, A. Diabat and G. Shatnawi, "Combining GIS with Multicriteria Decision Making for Siting Water Harvesting Ponds in Northern Jordan,” Journal of Arid Environments, Vol. 74, 2010, pp. 1471-1477. doi:10.1016/j.jaridenv.2010.07.001

[6] O. V. Barron, D. Pollock and W. Dawes, "Evaluation of Catchment contributing Areas and Storm Runoff in Flat Terrain Subject to Urbanization," Hydrology and Earth System Sciences, Vol. 15, 2011, pp. 547-559. doi:10.5194/hess-15-547-2011

[7] H. G. Coskun and E. Alparslan, "Environmental Modelling of Omerli Catchment Area in Istanbul, Turkey Using Remote Sensing and GIS Techniques," Environmental Monitoring and Assessment, Vol. 153, No. 1-4, 2002, pp. 323-332.

[8] H. Mitasova, J. Hofierka, M. Zlocha and L. R. Iverson, "Modelling Topographic Potential for Erosion and Deposition Using GIS," International Journal of Geographical Information Systems, Vol. 10, No. 5, 1996, pp. 629-641.

[9] H. Schäuble, O. Marinoni and M. Hinderer, “A GISBased Method to Calculate Flow Accumulation by Considering Dams and Their Specific Operation Time," Computers \& Geosciences, Vol. 34, No. 6, 2008, pp. 635646.

[10] S. Yu. Schreider, A. J. Jakeman, R. A. Letcher, R. J. Nathan, B. P. Neal and S. G. Beavis, "Detecting Changes in Stream Flow Response to Changes in Non-Climatic Catchment Conditions: Farm Dam Development in the 
Murray-Darling Basin, Australia,” Journal of Hydrology, Vol. 262, No. 1-4, 2002, pp. 84-98.

[11] S. A. Taqieddin, A. S. Al-Homoud, A. Awad and S. AlAyyash, "Geological and Hydrological Investigation of a Water Collection System in Arid Jordanian Lands," Environmental Geology, Vol. 26, No. 4, 1995, pp. 252-261. doi:10.1007/BF00770476

[12] R. Al-Adamat, "GIS as a Decision Support System for Siting Water Harvesting Ponds in Jordan," Journal of Environmental Assessment Policy and Management, Vol. 10 No. 2, 2008, pp. 189-206. doi:10.1142/S1464333208003020
[13] R. Al-Adamat, et al., "Predicted Soil Organic Carbon Stocks and Changes in Jordan between 2000 and 2030 Made Using the GEFSOC Modelling System,” In: E. Milne, D. S. Powlson and C. E. P. Cerri, Eds., Soil Carbon Stocks at Regional Scales, Journal of Agricultural Ecosystems and Environment, Vol. 122, No. 1, 2007, pp. 35-45.

[14] S. M. AlAyyash, F. N. Nnadi and R. S. Shatnawi, "A Surface Water Management Tool for Arid Lands Using GIS-A Jordan Badia Case Study,” In: R. W. Dutton and M. I. Shahbaz, Eds., Jordan's Arid Badia: Deepening Our Understanding, Smith-Gordon and Company, UK, 2008. 